\title{
Curriculum System Construction for Higher Vocational Civil Aviation Transportation Major Based on Work Process
}

\author{
Shi Yuehong \\ Sanya Aviation \&Tourism College, Hainan Sanya, 572000
}

Keywords: Civil aviation transportation major; Work process systematization; Curriculum system; Job post

\begin{abstract}
Curriculum system construction of civil aviation transportation major is discussed in this paper. Firstly, according to systematic working process theory, the characteristics of civil aviation transport professionals training are analyzed, the purpose of personnel training is discussed, and the main tasks of civil aviation transportation, the design of learning situation and study area conversion and how to build characteristic civil aviation courses are analyzed.
\end{abstract}

\section{Introduction}

In recent years, the development of China's civil aviation profession has been very fast. However, the demand for qualified personnel in civil aviation transportation has also been on the rise. Many colleges have also started to set up civil aviation transportation majors. These courses offered in colleges and universities are undergraduate professional enrichment, and the established courses are complicated with relatively little content about civil aviation cargo shipment [1-2]. Civil aviation transport major includes: ground aviation services, aviation commerce, civil aviation freight, air service and others, but the implementation of training objectives is rather vague. To improve the teaching characteristics of higher vocational colleges, the establishment of professional curriculum system is the key.

\section{Systematic curriculum system based on work}

\subsection{Curriculum system construction for civil aviation transportation major based on work process}

This article analyzes based on the tripartite linkage of "school, enterprise, and bank" mechanism establishment of an aeronautical university in Changsha, the university established a professional teaching system consisting of enterprises, schools and industry professionals. First of all, according to the relevant surveys on China Southern Airlines Co., Ltd., Shenzhen Airport, Hainan Airlines Co., Ltd. and Hunan Airport Co., Ltd., the demand for qualified personnel in these typical enterprises is analyzed. By investigating market situation, we found out that these corporations have relatively high demand for talents' ability, knowledge and quality, based on which professional training objectives are established [3-4]. Secondly, the demand for talent employment ability in civil aviation freight station is analyzed. The tasks, requirements, nature of the related positions and mutually recursive relations between various positions are discussed to analyze all aspects of requirements of each position on the ability of personnel, and each job contains project, tasks and work processes. Only with detailed understanding of these positions' standards for professional ability can talents be better trained. Furthermore, select typical tasks to summarize the function way. Finally, the instructional design is guided by the established typical work content to provide students with a good learning situation. The conclusion of the above analysis is transformed into teaching field to build a more scientific teaching system (See Figure 1). 


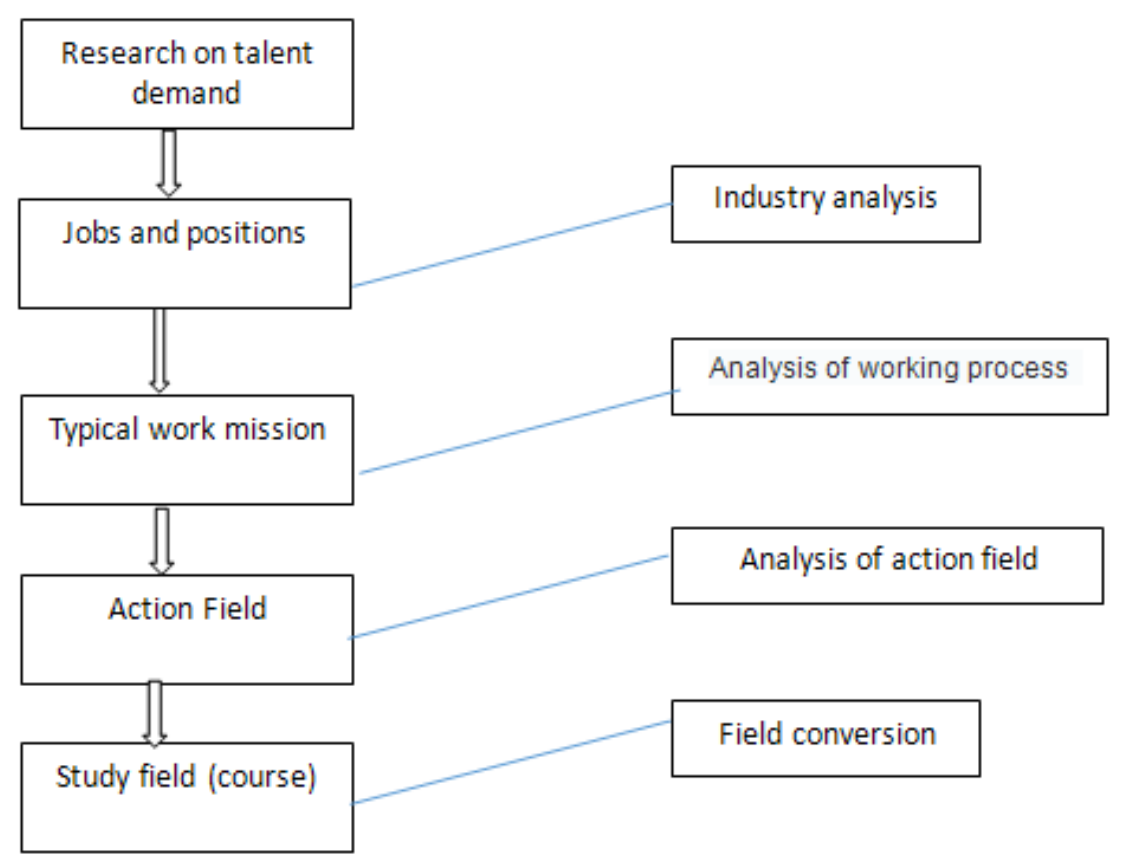

Figure 1 Civil aviation transport major’s course system development process

\subsection{The construction method for work process system development course system}

Based on the analysis of educational entities, the instructor needs to analyze the actual process of the work and integrate work practice into course construction from systematic perspective. Systematic work process curriculum system is not based on traditional logic of discipline; it is the establishment of graduation work rules curriculum list more progressive to reality rules based on the study of professional job areas' typical tasks and processes and with the guide of curriculum content planning. In fact, it is the establishment of educational tasks according to the law of career growth to provide help for the employment of students.

\section{Construction steps in establishing a professional curriculum system}

\subsection{Determine the goal of personnel training}

Research should be done on civil aviation freight forwarding companies. Set the goal of qualified personnel training in light of the actual conditions of the college with suggestions from professionals in the industry and enterprises. Fully reflect the management and service requirements of navigation airport, freight forwarding companies, civil a few games, airlines, and logistics companies, and improve the professional awareness of service and professionalism. In addition, students also need to improve the skills in air cargo delivery and receiving, cargo departure transport operations, international air cargo inspection and post-mortem delivery to promote the all-round development of students and provide more comprehensive quality professionals for the field of civil aviation enterprises.

\subsection{Job-oriented position analysis}

The professional market analysis of the operation helps the establishment of specific talent training objectives and the breakdown of professional work-specific links, including: initial posts and the developmental posts, and each position's talent demand is analyzed.

\subsection{Analyze typical tasks and establish action}

Actively hold business, industry and professional seminars. According to typical civil aviation transport professional positions, explore typical cargo civil aviation tasks and make integration and induction for typical job tasks, and thus establish the area of action. See Table 1. 


\subsection{Transformation of learning field}

According to social labor security, human resources and civil aviation sales agent job qualification certificates, establish industry and national occupational standards. Induce typical work and guide the curriculum construction according to work process. Transform the field of action into basic learning areas. With professional qualification standards, enrich professional learning content, and then professional courses are divided. Professional learning curriculum system is shown in Table 2.

\subsection{Learning scenario design}

According to occupational characteristics, the actual teaching is subdivided into thematic learning units. The establishment of learning scenarios is to truly imitate the actual job situation, so that students have the understanding of job task, so as to develop their professional ability. The establishment of learning scenarios can be based on the actual work site cases, such as teaching modules, projects, training tasks, civil aviation production site video, so that students have access to the actual work scenarios of their major, so as to strengthen their professional business context understanding. For example: "Civil Aviation Domestic Goods Transport" course requires students to understand the details of the operation of goods collection and transportation process, tag making hanging, documents, goods departure process. According to the requirements of this post, a learning scenario [5-6] was set up on the topics of "making and attaching all kinds of labels or making marks," "filling out consignments," and "filling domestic air waybills". For example: the establishment of "filling out consignments" situation is to make students fill in the consignment of goods on their own, and according to "an airport company general cargo" situation, complete the relevant tasks, simulate the real work situation, so as to train students professional ability and lay the foundation for students to engage in the professional work later.

Table 1 Civil aviation transportation major action area shaping

\begin{tabular}{|c|c|c|}
\hline $\begin{array}{l}\text { Serial } \\
\text { number }\end{array}$ & Typical tasks & Summarize action field \\
\hline 1 & $\begin{array}{l}\text { Audit documents, booking, with the cabin, } \\
\text { air cargo collection, shipping, customs } \\
\text { clearance, receiving labels }\end{array}$ & $\begin{array}{l}\text { International air freight } \\
\text { forwarding business }\end{array}$ \\
\hline 2 & $\begin{array}{l}\text { Outbound cargo storage, the cabin, board, } \\
\text { loading }\end{array}$ & $\begin{array}{l}\text { Loading cargo outbound } \\
\text { delivery }\end{array}$ \\
\hline 3 & $\begin{array}{l}\text { Hand over and take over port document, } \\
\text { flight to port unloading and pick-up, } \\
\text { sorting and warehousing, delivery of } \\
\text { goods inbound, receiving inbound cargo }\end{array}$ & $\begin{array}{l}\text { Hand over and takeover of } \\
\text { goods inbound }\end{array}$ \\
\hline 4 & $\begin{array}{l}\text { Processing of damaged cargo, cargo } \\
\text { handling flights, lost and others }\end{array}$ & $\begin{array}{l}\text { Handling of abnormal } \\
\text { goods }\end{array}$ \\
\hline 5 & $\begin{array}{l}\text { Receipt of outgoing goods and weighing, } \\
\text { billing, marking, security, labeling, } \\
\text { departure document operation }\end{array}$ & $\begin{array}{l}\text { Delivery of } \\
\text { outbound }\end{array}$ \\
\hline
\end{tabular}


Table 2 Civil aviation transport major’s learning area curriculum system

\begin{tabular}{|c|c|c|}
\hline Areas of action & Field of study & Corresponding courses \\
\hline $\begin{array}{l}\text { 1. Collection of outgoing } \\
\text { goods } \\
\text { 2. Handling abnormal goods } \\
\text { 3. Delivery, receiving } \\
\text { incoming goods } \\
\text { 4. Aviation international } \\
\text { business freight forwarding } \\
\text { 5. Delivery of goods out of the } \\
\text { harbor }\end{array}$ & $\begin{array}{lll}\text { Core } & \text { professional learning } \\
\text { areas } & & \end{array}$ & $\begin{array}{l}\text { Transport of dangerous civil } \\
\text { aviation goods } \\
\text { Aircraft balance and stowage } \\
\text { Test professional skills } \\
\text { Transport domestic civil } \\
\text { aviation goods } \\
\text { Comprehensive training freight } \\
\text { Warehouse management } \\
\text { Civil Aviation Cargo Transport } \\
\text { Training } \\
\text { Internships } \\
\text { Transport international civil } \\
\text { aviation goods } \\
\text { Logistics Express aviation } \\
\text { practice aviation } \\
\text { Transport civil a } \\
\text { passengers } \\
\text { Air transport marketing } \\
\text { Customs inspection and } \\
\text { customs clearance }\end{array}$ \\
\hline & $\begin{array}{l}\text { Professional basic learning } \\
\text { area }\end{array}$ & $\begin{array}{l}\text { Air transportation geography } \\
\text { Logistics management } \\
\text { foundation } \\
\text { Civil aviation English } \\
\text { Air transport management } \\
\text { Settlement, accounting civil } \\
\text { aviation transport } \\
\text { Introduction to International } \\
\text { Trade Aviation Psychology } \\
\text { Civil Aviation } \\
\text { Services } \\
\text { Civil aviation service etiquette } \\
\text { Civil aviation base } \\
\text { Civil Aviation Law }\end{array}$ \\
\hline & $\begin{array}{l}\text { Professional development of } \\
\text { learning areas }\end{array}$ & \begin{tabular}{l}
\multicolumn{2}{l}{ Civil aviation e-commerce } \\
Air transport economy \\
Constant flight customer \\
country overview \\
$\begin{array}{l}\text { Commercial Civil } \\
\text { negotiation skills }\end{array}$
\end{tabular} \\
\hline & & $\begin{array}{l}\text { Civil Aviation Customer } \\
\text { Relationship Management }\end{array}$ \\
\hline
\end{tabular}

\section{Build characteristic course system}

\subsection{Establish professional courses based on professional ability}

Change colleges' past knowledge-based teaching philosophy, implement ability-based instruction of curriculum teaching strategy, transform the principle of knowledge-oriented into action-oriented for actual teaching, and make clear talent literacy, skills goals, knowledge, and course content according to professional ability cultivation and actual job requirements.

\subsection{Clear skills requirements according to the vocational qualification standards}

According to students' demand for future professional posts, civil aviation major skill course standard should be established so that students can master civil aviation professional technical 
ability on the basis of practical teaching and theoretical teaching. At the same time, judge students' ability according to relevant qualifications certificates obtained from civil service post qualification certificate examination.

\subsection{Establish curriculum system by taking work process as the main line}

According to the idea of combining work and study, we should understand in detail the requirements of professional positions for talents' skills and knowledge, analyze the actual working conditions of civil aviation freight industry, summarize the typical job tasks of civil aviation freight transportation, as well as job requirements for qualified personnel so as to establish more scientific teaching system.

\subsection{Set learning situations based on work task}

According to the key tasks in each post, establish real teaching situations to help students transform the learned basics into practice allowing students to profoundly improve their understanding of the professional needs of actual job positions, so that students in a complex career relationship can improve their professionalism and professional comprehensive ability.

\section{References}

[1] Xu Xiaxin, Qi Qi, Xing Lei. Innovative Development of Civil Aviation International Ticket Sales Curriculum: A Case Study based on Third Party Evaluation Concept [J]. Air Transport Business, 2015 (4): 37-38.

[2] Chi Ruihong. Discussion on Cultivation of Service Consciousness of Flight Major Students ---Taking Guangzhou Civil Aviation Technical College as an Example [J]. Journal of Hunan Mass Media Vocational Technical College, 2015, 15 (5): 101-103

[3] Zhao Guihong, Ma Chunfang, Jiang Hong. Research on the Major Construction of Business Administration Major in Industrial Colleges ---- A Case Study of Business Administration Major Construction of Civil Aviation University of China [J]. Education Education Forum, 2017 (25): 98-99.

[4] Liu Chundi. Systematization of Higher Vocational "Foreign Trade Documentary Practice" curriculum system based on work process ---- Taking Shanghai Polytechnic University as an Example [J]. Advances in Education, 2015, 05: 61-64. 